\title{
Review of research on the mechanical properties of the human tooth
}

\author{
Ya-Rong Zhang*, Wen Du*, Xue-Dong Zhou and Hai-Yang Yu \\ 'Bronze teeth' reflect the mechanical properties of natural teeth to a certain extent. Their mechanical properties resemble those of a \\ tough metal, and the gradient of these properties lies in the direction from outside to inside. These attributes confer human teeth with \\ effective mastication ability. Understanding the various mechanical properties of human teeth and dental materials is the basis for the \\ development of restorative materials. In this study, the elastic properties, dynamic mechanical properties (visco-elasticity) and \\ fracture mechanical properties of enamel and dentin were reviewed to provide a more thorough understanding of the mechanical \\ properties of human teeth. \\ International Journal of Oral Science (2014) 6, 61-69; doi:10.1038/ijos.2014.21; published 18 April 2014
}

Keywords: dentin; enamel; fatigue crack growth; fracture toughness; mechanical property

\section{INTRODUCTION}

'Bronze teeth' reflect the mechanical properties of natural teeth to a certain extent. Their mechanical properties resemble those of a tough metal, and they vary from the outside to inside of teeth. These attributes confer human teeth with effective mastication ability. ${ }^{1}$ The unique mechanical properties of natural teeth enable them to perform the functions of incision, laceration, and grinding of food during mastication. ${ }^{2}$ To date, a material that can completely take the place of human teeth with regard to biological and mechanical properties has not yet been found. Human teeth have a more complicated structure, better mechanical properties and better biocompatibility than all dental restorative materials, including synthetic resin materials, ceramic materials and dental alloys. Understanding the various mechanical properties of natural teeth is the basis of dental restoration materials research and can provide a reference for evaluating the mechanical properties of new dental materials. ${ }^{3}$ The elastic properties, dynamic mechanical properties (visco-elasticity) and fracture mechanical properties of human enamel and dentin are reviewed in this article, thus providing a more comprehensive understanding of the mechanical properties of human teeth.

The mechanical properties of human teeth are determined by their structure and composition. The structure of natural teeth consists of enamel, dentin, cementum and dental pulp, the first three of which constitute the hard tissue of the human tooth and are characterized by unique mechanical properties. The composition and structure of teeth are presented in Table 1.
The enamel rod, a 'keyhole-like' structure with a diameter of approximately $5 \mu \mathrm{m}$, is perpendicular to the dentinal-enamel junction $^{4}$ and is mainly composed of hexagonal prism hydroxyapatite crystals with a 68-nm length, 26-nm diameter and 2-nm protein thickness. ${ }^{5}$ The hydroxyapatite crystals at the centre are parallel to the long axis of the rod itself; however, the crystals at the margin of the rod form a $45^{\circ}$ angle to the axis. ${ }^{6}$ Two crystals in the enamel meet at sharp angles and form a 'fish-scale' or 'keyhole-like' appearance referred to as the rod sheath. The rod sheath consists of more protein than other areas of the enamel and is hypomineralized compared with the remainder of the highly mineralized enamel. Thus, the enamel has an anisotropic mechanical property.

Dentin is the tissue that lies beneath the enamel and surrounds the pulp chamber and root canals. The dentin microstructure consists of dentinal tubules that radiate outward through the dentin from the pulp to the exterior cementum or enamel border. Peritubular dentin and intertubular dentin contain rich collagen fibres. The dentinal tubules are wrapped with peritubular dentin. The size, quantity and wall thickness of dentinal tubules vary from outside to inside. ${ }^{7}$

Cementum has a structure similar to that of bone tissue but has a lower hardness than dentin. The main inorganic components of cementum exist in the form of apatites that primarily contain calcium ion, and its organic components consist of collagen and noncollagen proteins. Cementum can be divided into acellular cementum and cellular cementum. The acellular cementum is formed by the cementum lamina, which is tightly attached to the surface of the

State Key Laboratory of Oral Diseases, West China Hospital of Stomatology, Sichuan University, Chengdu, China

*These authors contributed equally to this study.

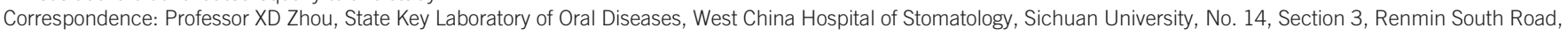
Chengdu 610041, China

E-mail: zhouxd@scu.edu.cn

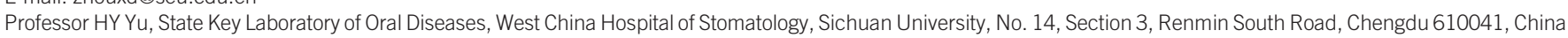
E-mail: yhyang6812@scu.edu.cn

Accepted 16 September 2013 
Table 1 General information on the human tooth structure

\begin{tabular}{|c|c|c|c|}
\hline Dental tissue & Enamel & Dentin & Cementum \\
\hline Composition & $96 \%$ inorganics, the rest are water and organics & $65 \%-70 \%$ minerals, the rest are organics & $\begin{array}{l}45 \%-50 \% \text { inorganics, } 50 \%-55 \% \text { water and } \\
\text { organics }\end{array}$ \\
\hline Microstructure & Enamel rods, enamel rod sheath & $\begin{array}{l}\text { Dentinaltubule, peritubular dentin, intertubular } \\
\text { dentin }\end{array}$ & Cellularcementum, acellularcementum \\
\hline $\begin{array}{l}\text { Microstructure } \\
\text { chart }\end{array}$ & 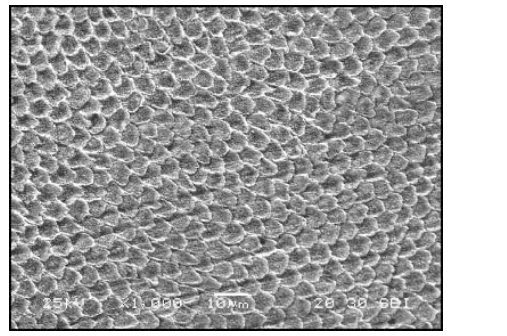 & 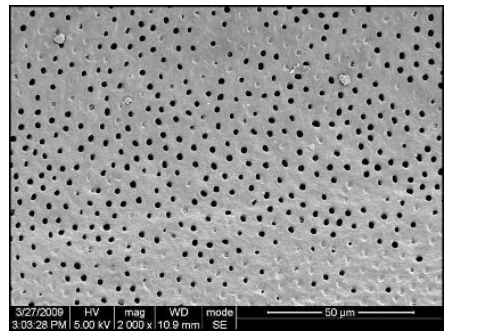 & 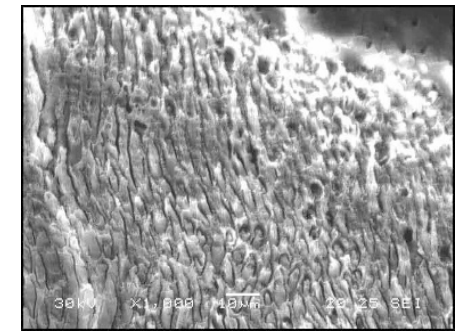 \\
\hline
\end{tabular}

intermediate cementum from the cervix to the site near the apical third of the root, whereas the cellular cementum is located on the surface of the acellular cementum or arranged alternately with acellular cementum at the apical third of the root. ${ }^{8}$ The unique gradient structure of natural teeth forms the basis of their anisotropic mechanical properties.

\section{MECHANICAL PROPERTY INDICES OF HUMAN TEETH}

The mechanical properties of teeth include elasticity, hardness, viscoelasticity and fracture behaviour.

Elasticity is a term used to describe the characteristic in which a material changes under external force and recovers after the force is removed. The elastic property indices of natural teeth primarily include the elastic modulus (ratio of normal stress to normal strain), shear modulus (ratio of shear stress to shear strain) and Poisson's ratio (ratio of transverse contraction strain to longitudinal extension strain in the direction of the stretching force). The elastic modulus is the property that has been studied most extensively. ${ }^{9}$

Hardness is a measure of the hardness or softness of a material and also represents the ability of a solid material to resist elastic deformation, plastic deformation and destruction. ${ }^{10}$ Measurements of the hardness of natural teeth have shifted from macroscopic to microscopic with the advancement of new methods, enabling the accurate measurement of hardness at different sites of an enamel rod. ${ }^{4}$

Visco-elasticity is used to characterize materials that exhibit both viscous and elastic characteristics when an external force is applied. The composite modulus is the index used to characterize the viscoelasticity of a material and is composed of the storage modulus and loss modulus. ${ }^{11}$

The fracture mechanical properties are used to study the strength and crack growth law of materials with crack-type defects. ${ }^{12}$ Studies on the fracture mechanical properties of teeth have focused on characterizing the fracture toughness and fatigue crack growth rate as well as establishing the crack growth law. These mechanical property indices provide the standards for evaluating natural teeth and also serve as the foundation for understanding natural human teeth as well as for developing new dental restorative materials.

\section{ELASTIC PROPERTIES AND HARDNESS OF ENAMEL AND DENTIN}

Most studies on the elastic modulus and hardness of natural teeth use a similar testing system and samples. In this study, we summarize the results regarding the elastic modulus and hardness of enamel and dentin.

\section{Elastic modulus and hardness}

The elastic modulus, also known as Young's modulus, is a value used to measure the rigidity of a material and is defined as the ratio of stress and strain under an elastic state. For human teeth, Young's modulus indicates the ability of enamel and dentin to resist elastic deformation. $^{13}$

Hardness is commonly used to characterize the ability to resist compression deformation and fracture of a local area of a material. The hardness of teeth can be divided into static hardness and dynamic hardness. ${ }^{14}$ The static indentation hardness test is the most commonly used method for characterisation. ${ }^{15}$ The frequently used indices for static indentation hardness include the Vickers hardness, Knoop hardness and nano-hardness.

The Vickers hardness can be obtained by calculating the bare testing force unit area in indentation. The indenter is a diamond square pyramid formed by opposite angles of $136^{\circ}$. The measured value is the quotient of the load to surface area of the indentation. ${ }^{13}$

The indenter used to measure the Knoop hardness also consists of a diamond square pyramid, but it is formed by two unequal opposite angles. The Knoop hardness equals the ratio of the load to the projected contact area. ${ }^{13}$

The microhardness is the hardness of materials measured using a load of $10 \mathrm{mN}$ to $10 \mathrm{~N} .^{14}$ The nano-hardness is the hardness of materials measured with a load of less than $700 \mathrm{mN}$, with indentation on the scale of microns or even nanometres. ${ }^{16}$

\section{Methods of measuring the hardness and elastic modulus of enamel} and dentin

The most widely used method to measure the hardness and elastic modulus of enamel and dentin is the nano-indentation technique, which enables the collection of measurements in the nano-scale range with the aid of a Berkovich indenter and a spherical indenter or via atomic force microscopy (AFM). The conical Vickers hardness tester and Knoop hardness indenter are used to measure hardness only. The nanoindentation system is applicable to measurements of both hardness and elastic modulus. A comparison of the methods is shown in Table 2.

\section{Hardness and elastic modulus of enamel}

The hardness and elastic modulus of enamel have been the overall emphases of research on the mechanical properties of human teeth. Early studies assumed that enamel was a type of isotropic material that had the same properties regardless of direction. However, due to a deeper understanding of tooth structure, researchers have discovered anisotropic mechanical properties. ${ }^{17-29}$ In research on the axial 
Table 2 Common methods of measuring and calculating hardness and elastic modulus ${ }^{14-16}$

\begin{tabular}{|c|c|c|c|c|c|c|c|}
\hline Hardness test & Shape of indenter & Load/N & $\begin{array}{l}\text { Depth of } \\
\text { indentation/ } \\
\mu \mathrm{m}\end{array}$ & Measuring method & Calculation formula & Applied range & $\begin{array}{l}\text { Advantages and } \\
\text { disadvantages }\end{array}$ \\
\hline $\begin{array}{l}\text { Vickers } \\
\text { hardness }\end{array}$ & $\begin{array}{l}\text { Diamond square, } \\
\text { pyramid formed } \\
\text { by an opposite } \\
\text { angle of } 136^{\circ}\end{array}$ & $\begin{array}{l}\text { 10-1 } 200, \\
\text { may be }<0.25 \\
<2 \text { or }<10 \\
\text { microhardness }\end{array}$ & $1-100$ & $\begin{array}{l}\text { Measure the diagonal } \\
\text { length of indentation } \\
D=\left(d_{1}+d_{2}\right) / 2\end{array}$ & $H_{\mathrm{V}}=1.854 P / D^{2}$ & $\begin{array}{l}\text { Measure the } \\
\text { macrohardness } \\
\text { and microhardness } \\
\text { of hard tissue of } \\
\text { teeth }\end{array}$ & $\begin{array}{l}\text { When load changes, the } \\
\text { geometry of } \\
\text { indentation remains } \\
\text { similar; but on } \\
\text { different scales, the } \\
\text { indenter geometry } \\
\text { cannot be similar }\end{array}$ \\
\hline $\begin{array}{l}\text { Knoops } \\
\text { hardness }\end{array}$ & $\begin{array}{l}\text { Diamond square, } \\
\text { pyramid formed } \\
\text { by two unequal } \\
\text { opposite angles } \\
\left(\alpha=172.5^{\circ} \text { and }\right. \\
\left.\beta=130^{\circ}\right)\end{array}$ & $\begin{array}{l}2-40,<0.01 \\
\quad<2 \text { or }<10 \\
\text { microhardness }\end{array}$ & $0.3-30$ & $\begin{array}{l}\text { Measure the long } \\
\text { diagonal length } \\
\text { of indentation }\end{array}$ & $\begin{array}{l}H_{K}= \\
\quad 0.102 \times 14.23 P / L^{2}\end{array}$ & $\begin{array}{l}\text { Measure the } \\
\text { macrohardness } \\
\text { and microhardness } \\
\text { of hard tissue of } \\
\text { teeth }\end{array}$ & $\begin{array}{l}\text { The sensitivity of } \\
\text { measuring the } \\
\text { variation of teeth } \\
\text { microstructure is } \\
\text { higher than Vickers } \\
\text { hardness }\end{array}$ \\
\hline $\begin{array}{l}\text { Berkovi- } \\
\text { chardness }\end{array}$ & $\begin{array}{l}\text { Triangular pyramid } \\
\text { forming an angle } \\
\text { of } 65.3^{\circ} \text { between } \\
\text { centreline and } \\
\text { conical surface }\end{array}$ & $\begin{array}{l}<0.5,<0.700 \\
\text { nanohardness }\end{array}$ & $0.001-1$ & $\begin{array}{l}\text { Real-time depth } \\
\text { and load } \\
\text { measurement } \\
\text { of indentation }\end{array}$ & $\begin{array}{l}H=\frac{P_{\max }}{A} \\
\frac{1}{E_{\mathrm{r}}}=\frac{1-V_{\mathrm{i}}^{2}}{E_{\mathrm{i}}} \\
E_{\mathrm{r}}=\frac{S \sqrt{\pi}}{2 \sqrt{A}} \\
S=\frac{\mathrm{d} P}{\mathrm{~d} h}\end{array}$ & $\begin{array}{l}\text { Measure the } \\
\text { microhardness } \\
\text { and nanohardness } \\
\text { of hard tissue of } \\
\text { teeth, as well as the } \\
\text { elastic modulus }\end{array}$ & $\begin{array}{l}\text { It can be real-time depth } \\
\text { and load } \\
\text { measurement of } \\
\text { indentation; hardness } \\
\text { and elastic modulus } \\
\text { can be measured at } \\
\text { the same time; on very } \\
\text { small scales, the } \\
\text { indenter geometry } \\
\text { can be similar, and } \\
\text { the results can be } \\
\text { compared with } \\
\text { Vickers hardness }\end{array}$ \\
\hline
\end{tabular}

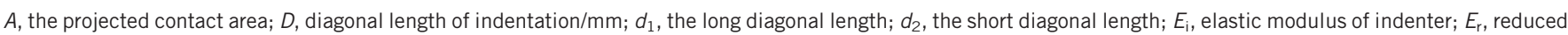

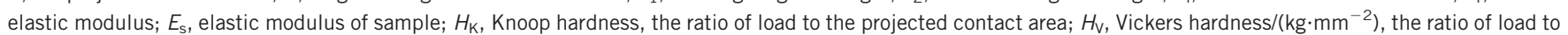
surface area; $L$, long diagonal length; $P$, load per kg; $P_{\max }$, maximum load; $S$, unloading stiffness; $V_{\mathrm{i}}$, Poisson's ratio of indenter; $V_{\mathrm{s}}$, Poisson's ratio of sample.

cross-sectional mechanical properties of enamel of the maxillary second molar, Cuy et al. ${ }^{30}$ found that the mechanical properties of enamel are related to factors including the location, chemical components and arrangement patterns of the enamel rods. The maximum hardness ( $3.5 \mathrm{GPa}$ ) of enamel is located on the surface, and the hardness decreases gradually with increasing depth, whereas the enamel maintains a stable hardness of $2-2.5 \mathrm{GPa}$ at a distance of $100-600 \mu \mathrm{m}$ from the dentin enamel junction (DEJ). ${ }^{31}$ The nano-hardness and elastic modulus decrease gradually from the surface of the enamel to the DEJ, and both are positively correlated with calcium content. ${ }^{24,30,32-39}$ Moreover, the hardness and elastic modulus of enamel are related to the array direction of the enamel rods. The anisotropic mechanical properties of enamel are well known. The mechanical property results vary distinctly with different positions on the same rod. ${ }^{17,23,28-29,40}$ Jeng et al. ${ }^{17}$ conducted further research on the anisotropic nano-mechanical properties of enamel rods and found that the hardness and elastic modulus of the heads of the enamel rods are distinctly greater than those of the tail and axial cross-section. The mechanical properties of the enamel exhibit a spatial correlation function based on analysis at a microscopic level. ${ }^{17}$ The hardness and elastic modulus decrease from the head to tail of the same enamel rod, mostly due to the change in the crystal array directions inside the enamel and organic contents. ${ }^{4,38,41}$ The reported mechanical property index values vary between studies (Table 3 ).
The results of tooth hardness and elastic modulus vary between research groups, possibly due to the influence of external factors, i.e., measuring system, shape of indenter, applied load, sample natures and direction of the enamel rod. However, the dryness or hydration of the environment and the tooth position had little influence on the tooth hardness and elastic modulus.

The most frequently used nano-indentation systems include the ultra-micro-indentation system (UMIS-2000; Commonwealth Scientific and Industrial Research Organisation, Campbell, Australia) with a Berkovich indenter, the Triboscope indenter system (HysitronInc, Minneapolis, MN, USA), the Nanoindenter XP (MTS Systems Corp, Minneapolis, MN, USA) and the CSM indentation tester (CSM, Peseux, Switzerland). ${ }^{42-52}$ Among all the existing micromeasuring systems, the MTS yields the highest values (hardness of 6-7 GPa, elastic modulus of $120-130 \mathrm{GPa}$ ). The UMIS can obtain measurements of dental tissue in a hydrated environment similar to that in vivo. ${ }^{53}$ However, this system does not provide full control of the precise position of indentation and requires over 100 indentation points for every surface; thus, this method cannot measure the hardness of a single crystal. ${ }^{54}$ The Triboscope indenter system can collect measurements on the nanometre scale and can precisely measure and obtain images of the indentation point with the aid of AFM. ${ }^{4}$ The mechanical properties of different length 
Table 3 Results of enamel hardness and elastic modulus measurement

\begin{tabular}{|c|c|c|c|c|c|}
\hline Author & Method and indenter & Site & Load & Hardness/GPa & Elastic modulus/GPa \\
\hline E Mahoney (2000) & UIMS, Berkovich indenter & 1st molar & $\begin{array}{l}50 \mathrm{mN} \\
150 \mathrm{mN}\end{array}$ & $\begin{array}{l}4.88 \pm 0.41 \\
4.87 \pm 0.29\end{array}$ & $\begin{array}{l}80.94 \pm 6.65 \\
79.77 \pm 8.86\end{array}$ \\
\hline S Habelitz (2001) & $\begin{array}{l}\text { Nanoindentation, sharp cube } \\
\text { shaped diamond indenter }\end{array}$ & 3rd molar & $1500 \mu \mathrm{N}$ & $\begin{array}{l}\text { Parallel to rod } 3.9 \pm 0.3 \\
\text { Perpendicular to rod } 3.3 \pm 0.3 \\
\text { Head } 4.3 \pm 0.4 \\
\text { Middle } 3.7 \pm 0.4 \\
\text { Tail } 3.9 \pm 0.4\end{array}$ & $\begin{array}{l}\text { Parallel to rod } 87.5 \pm 2.2 ; \\
\text { Perpendicular to rod } \\
\quad 72.7 \pm 4.5 ; \\
\text { Head } 88.0 \pm 8.6 \text {; } \\
\text { Middle } 88.0 \pm 8.6 \text {; } \\
\text { Tail } 86.4 \pm 11.7\end{array}$ \\
\hline SF Ang $(2009,2010)$ & $\begin{array}{l}\text { Nanoindentation, spherical } \\
\text { indenter }\end{array}$ & 3rd molar & $\begin{array}{l}5-11 \mathrm{mN} \\
0.4 \mathrm{mN}\end{array}$ & $5.7 \pm 0.3$ & $\begin{array}{l}123 \\
86.4 \pm 11.7\end{array}$ \\
\hline B He (2010) & Knoop hardness indenter & 3rd molar & $50 \mathrm{~g}$ & $\begin{array}{l}\text { Lingual } 352.5 \pm 23.3 \\
\text { Buccal } 351.7 \pm 42.1\end{array}$ & \\
\hline Y-R Jeng (2011) & $\begin{array}{l}\text { Nanoindentation, Berkovich } \\
\text { indenter }\end{array}$ & Premolar & & $\begin{array}{l}\text { Head } 5.01 \pm 0.27 \\
\text { Tail } 4.52 \pm 0.18 \\
\text { Cross-section } 4.58 \pm 0.23\end{array}$ & $\begin{array}{l}102.56 \pm 3.01 \\
97.30 \pm 3.96 \\
97.72 \pm 3.09\end{array}$ \\
\hline JL Cuy (2002) & $\begin{array}{l}\text { Nanoindentation, Berkovich } \\
\text { indenter }\end{array}$ & 2nd, 3rd molar & $\begin{array}{l}400 \text { or } 800 \mathrm{~nm} \\
\text { in depth }\end{array}$ & $\begin{array}{l}\text { Surface }>6 \\
\text { Near DEJ }<3\end{array}$ & $\begin{array}{l}\text { Surface }>115 \\
\text { Near DEJ }<70\end{array}$ \\
\hline ME Barbour (2003) & $\begin{array}{l}\text { Nanoindentation, Berkovich } \\
\text { indenter }\end{array}$ & 3rd molar & $\begin{array}{l}3000 \mu \mathrm{N} \\
5000 \mu \mathrm{N} \\
7000 \mu \mathrm{N}\end{array}$ & $\begin{array}{l}4.81 \pm 0.15 \\
4.77 \pm 0.13 \\
4.75 \pm 0.12\end{array}$ & $\begin{array}{l}99.6 \pm 1.8 \\
101.9 \pm 1.6 \\
105.2 \pm 1.3\end{array}$ \\
\hline EK Mahoney (2004) & UIMS, Berkovich indenter & 1st molar & $20 \mathrm{mN}$ & $3.66 \pm 0.75$ & $75.57 \pm 9.98$ \\
\hline J Ge (2005) & $\begin{array}{l}\text { Nanoindentation, Berkovich } \\
\text { indenter }\end{array}$ & 3rd molar & $\begin{array}{l}1000 \mu \mathrm{N} \\
300 \mu \mathrm{N}\end{array}$ & $\begin{array}{l}\text { Rod } 4.3 \pm 0.8 \\
\text { Sheath } 1.1 \pm 0.3\end{array}$ & $\begin{array}{l}\text { Rod } 83.4 \pm 7.1 \\
\text { Sheath } 39.5 \pm 4.1\end{array}$ \\
\hline LH He (2006, 2009) & $\begin{array}{l}\text { Nanoindentation, Berkovich } \\
\text { indenter and spherical } \\
\text { indenter }\end{array}$ & Premolar & $\begin{array}{l}450 \mathrm{mN} \\
25 \mathrm{mN}\end{array}$ & $\begin{array}{l}\text { Surface } 5 \pm 0.45 \\
\text { Cross-section } 4.5 \pm 0.45 \\
\text { Inner layer } 3.05 \pm 0.41 \\
\text { Outer layer } 3.98 \pm 0.19\end{array}$ & $\begin{array}{l}\text { Surface } 60-100 \\
\text { Cross-section } 40-80 \\
\text { Inner layer } 56.80 \pm 5.39 \\
\text { Outer } 82.67 \pm 1.80\end{array}$ \\
\hline B-B An (2012) & $\begin{array}{l}\text { Nanoindentation, Berkovich } \\
\text { indenter }\end{array}$ & Molar & $3 \mathrm{mN}$ & & $\begin{array}{l}\text { Surface 80; } \\
\text { Middle layer 68; } \\
\text { Inner layer } 60\end{array}$ \\
\hline A Braly (2007) & $\begin{array}{l}\text { Nanoindentation, Berkovich } \\
\text { indenter }\end{array}$ & 3rd molar & & $6-7$ & $120-130$ \\
\hline S Roy (2008) & Conical Vickers tester & 3rd molar & $160 \mathrm{~g}$ & $\begin{array}{l}\text { Near surface } 3.5 \text {; } \\
\text { Near DEJ 2-2.5 }\end{array}$ & \\
\hline S Park (2008) & $\begin{array}{l}\text { Nanoindentation, Berkovich } \\
\text { indenter and Vickers } \\
\text { hardness tester }\end{array}$ & 3rd molar & & $\begin{array}{l}\text { Young: inner } 3.1 \text {; middle } 3.5 \text {; outer } 4.1 \\
\text { Aged: inner } 3.0 \text {; middle } 3.4 \text {; outer } 4.0\end{array}$ & $\begin{array}{l}75 ; 82 ; 87 \\
79 ; 90 ; 100\end{array}$ \\
\hline
\end{tabular}

DEJ, dentinoenamel junction; UIMS, ultra-micro-indentation system.

ranges of enamel are diverse because of the hierarchical structure and anisotropy of the enamel. ${ }^{28}$

The shape of the indenter influences the measurement to a certain extent. The Berkovich indenter can yield a relatively stable result, but the hardness increases gradually with contact depth and strain using a spherical indenter. The results obtained at the same contact depth vary with different indenters. ${ }^{29}$ The results obtained using the same measurement system are related to the load applied, and the greater the load, the lower the hardness and elastic modulus values due to an increase in energy dissipation via the development of cracks and brittle fracture. $^{50}$

Park et al..$^{21,28,53-56}$ measured the enamel hardness and elastic modulus in the teeth of individuals of different ages and found that both the hardness and elastic modulus of old permanent tooth enamel are higher than those of young tooth enamel. The thickness of the enamel changes due to the abrasion of the cusps with increasing age. The mineral content increases with age, resulting in higher hardness and elastic modulus values in old permanent teeth. Differences exist in the mechanical properties of enamel rods in different directions. When the indentation direction is parallel to the array direction of the rods, the elastic modulus is $(87.5 \pm 4.5) \mathrm{GPa}$ and the hardness is $(3.9 \pm 0.3) \mathrm{GPa}$. These values are $(72.7 \pm 4.5)$ and $(3.8 \pm 0.4) \mathrm{GPa}$, respectively, when the indentation direction is perpendicular to the array direction of the rods. ${ }^{4}$

These results show that higher hardness and elastic modulus values can be obtained in a perpendicular direction. For the enamel, the macroscopic and microscopic measurement results provide a holistic and local understanding of the mechanical properties of enamel, which can serve as a fundamental mechanical reference for the manufacture of artificial enamel with tissue engineering.

\section{Hardness and elastic modulus of dentin}

Studies on dentinal mechanical properties have focused on the properties of the microstructures, similar to studies on the mechanical properties of enamel. However, dentin has a more complex structure. The factors influencing the dentinal mechanical properties include the location, density and direction of the dentinal tubules; the direction of the collagen fibres; and the average density of the mineral phase. ${ }^{3}$ The results of the dentinal mechanical properties vary between studies (Table 4).

Wang et al. ${ }^{57}$ found that the micro-hardness of dentin adjacent to the DEJ is low, increases rapidly to a peak and decreases slowly towards the pulp cavity. The variation of the hardness and elastic modulus has 
Table 4 Mechanical properties of dentin

\begin{tabular}{|c|c|c|c|c|c|}
\hline Author & Direction and Indenter & Tooth Position & Load & Hardness/GPa & Elastic modulus/GPa \\
\hline E Mahoney (2000) & UIMS, Berkovich indenter & 1st molar & $\begin{array}{l}50 \mathrm{mN} \\
150 \mathrm{mN}\end{array}$ & $\begin{array}{l}0.95 \pm 0.11 \\
0.90 \pm 0.09\end{array}$ & $\begin{array}{l}20.55 \pm 2.00 \\
19.22 \pm 1.84\end{array}$ \\
\hline M Balcooh (2001) & $\begin{array}{l}\text { Nanoindentation, sharp } \\
\text { cube shaped diamond } \\
\text { indenter, dry environment }\end{array}$ & Root dentin & $30000 \mu \mathrm{N}$ & $\begin{array}{l}\text { Intertubular dentin 0.5-0.8; } \\
\text { Peritubular dentin 2.2-2.6 }\end{array}$ & $\begin{array}{l}\text { Intertubular dentin: 24-25; } \\
\text { Peritubular dentin: 40-45 }\end{array}$ \\
\hline L Angker (2003) & $\begin{array}{l}\text { UIMS, Berkovich indenter, } \\
\text { moist environment }\end{array}$ & $\begin{array}{l}\text { 1st molar, } \\
\text { dentin of crown }\end{array}$ & $25 \mathrm{mN}$ & $\begin{array}{l}\text { Dentin nearest the } \\
\text { pulp wall } 0.52 \pm 0.24 \\
\text { Dentin in the middle } \\
\text { area } 0.85 \pm 0.19 ; \\
\text { Dentin nearest dentinoenamle } \\
\text { junction } 0.91 \pm 0.15\end{array}$ & $\begin{array}{l}\text { Dentin nearest the pulp } \\
\text { wall } 11.59 \pm 3.95 ; \\
\text { Dentin in the middle } \\
\text { area } 17.06 \pm 3.09 ; \\
\text { Dentin nearest dentinoenamle } \\
\text { junction } 16.33 \pm 3.83\end{array}$ \\
\hline JH Kinney (2004) & $\begin{array}{l}\text { Resonant ultrasound } \\
\text { spectroscopy }\end{array}$ & $\begin{array}{l}\text { 3rd molar, } \\
\text { dentin of crown }\end{array}$ & $\begin{array}{l}\text { Vibration } \\
\text { frequency: } \\
\text { 0.5-1.4 MHz }\end{array}$ & & $\begin{array}{l}\text { Hydrated: } 25.1 \\
\text { Dry: } 28.1\end{array}$ \\
\hline SR Cohen (2008) & $\begin{array}{l}\text { Nanoindentation, sharp } \\
\text { cube shaped diamond } \\
\text { indenter, dry environment }\end{array}$ & Molar & & $\begin{array}{l}\text { Lumen edge } 4 \pm 0.5 \text {; } \\
\text { Between lumen and mid- } \\
\quad \text { peritubular dentin } 4.7 \pm 0.8 \text {; } \\
\text { Between mid-peritubular dentin } \\
\text { and intertubular dentin } 1.8 \pm 0.4 \text {; } \\
\text { Within intertubular dentin } 1.2 \pm 0.2\end{array}$ & \\
\hline W Franzel (2009) & Nanoindentation & Molar & & $0.78 \pm 0.1$ & $22.4 \pm 2.6$ \\
\hline D Ziskind (2011) & $\begin{array}{l}\text { Nanoindentation, } \\
\text { Berkovich indenter }\end{array}$ & $\begin{array}{l}\text { 3rd molar, } \\
\text { premolar, } \\
\text { dry } \\
\text { environment }\end{array}$ & $200-300 \mu \mathrm{N}$ & $\begin{array}{l}\text { Peritubular dentin } 1.34 \pm 0.5 \\
\text { Intertubular } 0.60 \pm 0.2\end{array}$ & $\begin{array}{l}\text { Peritubular dentin } 29.3 \pm 6.7 \\
\text { Intertubular dentin } 17.4 \pm 3.5\end{array}$ \\
\hline YL Chan (2011) & Nanoindentation & Molar & & $1 \pm 0.1$ & $19 \pm 2$ \\
\hline $\begin{array}{l}\text { LE Bertassoni } \\
\text { (2012) }\end{array}$ & UIMS, Berkovich indenter & 3rd molar & $50 \mathrm{mN}$ & $\begin{array}{l}\text { Dry environment } 1.43 \pm 0.12 \\
\text { Hydrated environment } 0.88 \pm 0.11\end{array}$ & \\
\hline C-F Han (2012) & $\begin{array}{l}\text { Nanoindentation, } \\
\text { dry environment }\end{array}$ & Molar & & $\begin{array}{l}10^{\circ} \text { to dentinal tubule: } 0.588 \\
80^{\circ} \text { to dentinal tubule: } 0.521\end{array}$ & $\begin{array}{l}10^{\circ} \text { to dentinal tubule: } 16.15 \\
80^{\circ} \text { to dentinal tubule: } 13.28\end{array}$ \\
\hline
\end{tabular}

UIMS, ultra-micro-indentation system.

a linear correlation according to statistical analysis results. ${ }^{53}$ The middle portion of the dentin has a higher hardness and elastic modulus than the outer portions, which is significant for clinical tooth preparation. Cohen et al. ${ }^{3}$ assessed the microstructural mechanical properties of dentin with AFM, with which they measured the hardness and elastic modulus of the lumen edge, peritubular dentin, peritubularintertubular junction (PIJ) and intertubular dentin. The results showed that the microstructural mechanical properties vary with different positions in the dentin. The hardness decreases gradually from the dentinal tubule cavity wall to the intertubular dentin and corresponds to the decrease in mineral content.

The mechanical properties of dentin vary according to mineral content. Highly mineralized peritubular dentin has a Young's modulus of 40-42 GPa, whereas weakly mineralized intertubular dentin has a Young's modulus of $17 \mathrm{GPa} .{ }^{58}$ Close to the pulp chamber, the hardness of the peritubular dentin (PTD) exhibits an evident gradient variation with the variation in mineral content. No such variation is observed at the DEJ. ${ }^{3}$ Angker et al. ${ }^{59}$ studied the relationship between the mechanical properties of carious dentin and mineral components and found that the decrease in the elastic modulus and hardness of carious dentin is directly related to and has an exponential relationship with mineral content. The transparency and mineral concentration increase as dentin ages, whereas the crystal size decreases. However, the elastic modulus does not significantly change. Due to the decreased organic content and deposition of minerals in the dentinal tubules, transparent dentin fractures emerge without yielding and directly present as the formation and growth of microcracks. ${ }^{60}$ The hardness and elastic modulus of dentin vary little with age. However, dentin becomes more brittle with mineral deposition; thus, its buffer capacity decreases, and teeth are more likely to fracture and crack. The mechanism, prevention and treatment of dentin brittleness warrant further investigation.

The mechanical properties of dentin are closely related to its internal structure and composition as well as the external environment. A study showed that the elastic modulus decreases by $35 \%$ and the hardness decreases by $30 \%$ in a hydrated environment. ${ }^{61}$ Kinney et al. ${ }^{62}$ confirmed that dentin is anisotropic in a moist environment. The value of $\mathrm{E}$ is equal to $25.1 \mathrm{GPa}$ in the direction perpendicular to the tubules, a value that is slightly higher than that in the parallel direction. Nevertheless, dentin becomes isotropic in a dry environment, with $E=28.1 \mathrm{GPa}^{62}$ Another study showed that the visco-elastic reaction of the dentin is stronger in dry environments, whereas the hardness and elastic modulus decrease. ${ }^{63}$ These studies indicate that the mechanical properties of dentin are greatly influenced by the environment. Thus, environmental factors should be taken into consideration in research studies. The macro- and micromechanical properties of dentin vary in different environments. The question of whether the ability to resist external forces, crack formation and growth changes in different environments requires further research. However, guidelines on the application and improvement of clinical techniques can still be developed, especially for teeth with the root canal treatment. The mechanical properties of teeth can be greatly influenced by hydrated environments after treatment. Thus, the use of lubricating media should be considered in future treatments. 


\section{DYNAMIC MECHANICAL PROPERTIES OF ENAMEL AND DENTIN}

Nanodynamic mechanical property analysis is used to determine material visco-elasticity and measure the storage modulus and loss modulus. ${ }^{46}$ The storage modulus describes the elastic reaction of materials, whereas the loss modulus describes the viscosity properties. ${ }^{46}$ The storage modulus measures the energy stored due to elastic deformation in the material deformation process and represents the elastic portion of the deformation. The loss modulus measures the energy dissipated as heat due to viscous deformation and represents the viscous portion. Materials exhibit elastic deformation primarily in the solid state when the storage modulus is much greater than the loss modulus; in contrast, materials exhibit viscous deformation primarily in the liquid state. When the storage modulus is equivalent to the loss modulus, the material exists in a semisolid state, i.e., a gel.

The storage and loss moduli are defined as follows ( $E^{\prime}$ is the storage modulus, $E^{\prime \prime}$ is the loss modulus):

$$
E^{\prime}=\frac{k_{s} \sqrt{\pi}}{2 \sqrt{A}} E^{\prime \prime}=\frac{\omega c_{s} \sqrt{\pi}}{2 \sqrt{A}} \tan \delta=\frac{\omega c_{s}}{k_{s}}
$$

where $A$ is the projected contact area, $\omega$ is the frequency of force applied, $C$ is the damping factor and $k$ is the system stiffness.

Balooch et al. ${ }^{64}$ combined AFM with a force-displacement sensor and measured the maximum width of the DEJ, which was approximately a quarter of that of enamel without plastic deformation, using modulus mapping; the storage modulus of enamel close to the DEJ was 51-74 GPa (average: $63 \mathrm{GPa}$ ). The width of the peritubular-intertubular junction is nearly half that of the PTD. The PTD is more highly mineralized and has a greater mean storage modulus than the ITD. The mean storage modulus of the intertubular dentin (ITD) is $21 \mathrm{GPa}$, whereas that of the PTD is $48 \mathrm{GPa}$. The organic collagen fibres of dentin are concentrated in the ITD; thus, the energy dissipation of the ITD is high, and the loss modulus of the ITD is greater than those of the enamel and PTD. ${ }^{62}$ The greater the loss modulus of dental tissue, the more viscous it is and the more difficult it is to fracture.

Ryou et al. ${ }^{46}$ investigated the dynamic mechanical properties of the PTD and ITD in a wet environment and discovered that the mean composite and storage moduli (19.6 and 19.2 GPa, respectively) are much lower than those of the PTD (31.1 and $30.3 \mathrm{GPa}$, respectively). The storage modulus represents the energy stored in the elastic deformation of dental tissue and is primarily influenced by the structure and composition of dental tissues. However, the loading frequency and quasistatic load have little influence on the storage modulus. The loss modulus represents the energy dissipation resulting from viscous deformations of dental tissue and increases with decreasing indentation load and increasing loading frequency. ${ }^{61}$

Currently, only a few studies on the dynamic mechanical properties of hard dental tissue are available, and, moreover, they are mainly focused on dentin. A study focusing on enamel has not yet been reported. Inorganics account for a large proportion of dental tissue, and dental tissue presents elastic properties and visco-elasticity, which are not the focus of this research. However, measurement of viscoelasticity requires real-time monitoring of the elastic and plastic deformation of nanodental structures and detection of energy variation with a highly developed measuring system. With the development of future measuring techniques, we believe that the dynamic mechanical properties of dental tissue can be more closely examined in different external environments and under various loading patterns. In addition, the combination of the analyses of dynamic and fracture mechanical properties can be applied to further elucidate the fracture mechanism of dental tissue.

\section{FRACTURE MECHANICAL PROPERTIES OF ENAMEL AND DENTIN}

Fracture mechanical property indices and measurement methods

The fracture mechanical properties of natural teeth include the fracture toughness and fatigue crack growth rate. The fracture toughness represents the ability of a material to resist fracture. The higher the fracture toughness of dental tissue, the higher the fracture stress and critical crack size, indicating greater resistance to fracture. ${ }^{12}$

Fracture mechanical properties are usually measured by applying a quasistatic load to specimens, detecting the crack growth and fracture toughness, measuring the crack length with a compliance method, ${ }^{56}$ and, finally, combining the load values with related fracture mechanical property formulas to calculate the fracture toughness. Indices representing the ability of dental tissue to resist fracture, i.e., flexural strength, fracture strength and fracture energy, can be obtained simultaneously during measurements. The fracture toughness $K_{\mathrm{IC}}$ is the critical value of the stress intensity factor $K_{\mathrm{I}}$ for in-plane deformation and small-scale yielding, such that crack tips must exist in this condition for the measurement of $K_{\mathrm{IC}}{ }^{12}$ Threeor four-point bending notched specimens and compact tension specimens are generally used. For three-point bending notched specimens, the tester indenter applies pressure to the upper centre of the specimens, and cracks are generated with tensile stress at the site of the lower notch. ${ }^{65}$ For four-point bending specimens, the flexural strength, fracture strength and fracture energy are measured. ${ }^{66}$ For compact tension specimens, dental tissue is wrapped with resin, and the insertion position of the dental tissue is calculated using finite element analysis. ${ }^{67-68}$ Holes are introduced in the square resin for pin passage to enable the application of tensile loads. Cracks are generated with the tensile stress at the site of the notch and grow with increasing stress. ${ }^{69}$

The fatigue process consists of crack initiation, stable crack extension and, finally, rapid crack propagation, a large proportion of which is accounted for by stable crack extension. ${ }^{70-71}$ Stable crack extension is an important determinant of the fatigue life of the entire dental tissue. In fatigue crack growth experiments with dental tissue, fatigue crack growth is defined using the following Paris formula:

$$
\frac{\mathrm{d} a}{\mathrm{~d} N}=C(\Delta K)^{m}
$$

The incremental crack extension $\mathrm{d} a$ is recorded, the number of cycles $\mathrm{d} N$ is assessed and the fatigue crack growth rate $\mathrm{d} a / \mathrm{d} N$ is calculated. The stress intensity $K$ is obtained from the crack size, specimen size and load, and $C$ and $m$ are material constants related to, e.g., the dental tissue, stress ratio and environment.

The specimen used to measure the fatigue crack growth of dental tissue is the same as that used to measure fracture toughness. Loads with a certain frequency and stress ratio are applied circularly to the tissue, which cracks at sites of notch growth with increasing cycles. ${ }^{72}$ The crack length is measured by optical microscopy and a compliance method. ${ }^{63}$ The fracture mode and fracture toughness are analysed using quantitative fracture topography. ${ }^{73}$ Other methods include an indentation method to measure crack growth. ${ }^{74}$ 
Some researchers believe that due to the presence of collagen fibres in the dentin, measurements using linear elastic fracture mechanics $\left(K_{\mathrm{c}}\right)$ neglect the influence of plastic deformation and may underestimate the toughness of dentin. ${ }^{67,75-76}$ Therefore, the fracture mechanical properties of dentin should be evaluated using elastic-plastic fracture mechanics. ${ }^{75}$

\section{Fracture properties of enamel}

Studies on the fracture mechanical properties that are limited by enamel size primarily focus on the crack growth law of enamel. Inside the enamel, initial cracks are generated at the hypocalcified EDJ and enamel tuft. ${ }^{77}$ Padmanabhan et al. ${ }^{74}$ studied the enamel crack growth law using a micro-indentation technique and found that crack resistance increases with increasing crack length. However, only crack resistance could be obtained with the indentation method; crack toughness could not be measured.

From the viewpoint of microstructure, the cracks are semicircular in shape and grow along the direction of the enamel rods, as assessed using a micron indentation technique. ${ }^{69}$ Using a fracture mechanical method, Padmanabhan et al. ${ }^{74}$ showed that enamel cracks propagate along the rod sheath. The direction of crack growth forms an angle of a certain degree with the initial crack tip, which is related to the direction of the rods and hydroxyapatite crystals as well as protein shearing.

Researchers have measured the fracture toughness of external and internal enamel as $(0.67 \pm 0.12) \mathrm{MPa} \cdot \mathrm{m}^{0.5}$ and $1.13-3.93 \mathrm{MPa} \cdot \mathrm{m}^{0.5}$, respectively, using a fracture mechanical method. The internal enamel shows strong resistance to fracture. Crack resistance increases externally to internally, meaning that crack growth becomes more difficult from outside to inside. ${ }^{78-79}$

Bajaj et al. ${ }^{72}$ compared the fracture properties of enamel and Hap, which have similar crystallinity, chemical composition and density values. These researchers discovered that cracks grow along the edge of rods. Crack bridging, crack deflection and crack bifurcation appear in regions of decussation. These mechanisms collaborate to increase the crack growth resistance, but a non-similar mechanism is found in Hap.

\section{Fracture properties of dentin}

In early studies on fracture properties, dentin fracture was found to be anisotropic when the crack growth direction forms different angles with the dentinal tubules. ${ }^{80}$ The fracture property of dentin is related to its complex microstructure. Root dentin has a higher fracture resistance than coronal dentin because of the lack of PTD. The fracture behaviour of root dentin is highly anisotropic, and the incremental lines are the weakest planes. However, coronal dentin exhibits brittle fracture along the PTD. Highly mineralized PTD intersects with the incremental lines, which greatly reduces the degree of fracture anisotropy. ${ }^{81}$

Dentin undergoes an increase in fracture resistance with crack extension (rising $R$-curve behaviour). ${ }^{54} \mathrm{~A}$ complicated internal and external toughening mechanism occurs in the process of crack growth. This internal toughening mechanism primarily describes the large amount of microcracks at the crack tip, which induces energy dissipation. Plastic deformation at the crack tip causes further energy dissipation. ${ }^{76}$ An external toughening mechanism indicates the existence of crack bridging in unbroken ligaments of dentin, which causes crack deflection and crack bifurcation. These mechanisms can lower the crack tip stress and increase the crack growth resistance. ${ }^{65}$
The factors influencing dentinal fracture mechanical properties include moisture, age and indentation direction, as well as the complicated microstructure of dentin. ${ }^{82}$ Dentin in young permanent teeth has an average fatigue crack growth exponent of $m=13.3 \pm 1.1$ in a hydrated environment, which is lower than that of dentin in a dry environment $(m=18.8 \pm 2.8)$. Crack bridging, crack deflection and crack bifurcation in young hydrated dentin assist energy dissipation and increase crack growth resistance. The fatigue crack growth resistance is reduced in dry environments. ${ }^{56}$

Age has a large influence on dentinal crack growth; specifically, aged dentin has lower initial toughness $\left(K_{\mathrm{o}}\right)$ and stable toughness $\left(K_{\mathrm{p}}\right)$ values compared with young dentin. ${ }^{79}$ The dentinal tubules of young dentin almost always exist in an open state rather than as filled with hydroxyapatite. Crack growth in young dentin produces severe crack deflection, which reduces the local stress intensity and blocks further crack growth. At the same time, microcracks are generated near open dentinal tubules. Microcracks do not completely merge to form the main crack tips. These unbroken ligaments of dentin induce crack bridge formation and block crack growth. No microcracking is found at closed dentinal tubules. ${ }^{81}$

Arola et al. measured the fatigue crack growth exponent in the directions of $0^{\circ}, 45^{\circ}$ and $90^{\circ}$ to the dentinal tubules. If the direction is $90^{\circ}$ to the tubules, $m=13.3 \pm 1.1$, which is higher than that if the direction is $45^{\circ}(m=11.5 \pm 1.87)$. These researchers also found that the process from fatigue to fatigue crack growth occurs with minimum cyclic stress when the dentinal tubules align at cyclic normal stresses. $^{54}$

For dentin, researchers use a micron indentation technique or a fracture mechanical method to understand the microstructural crack growth mechanism and the influence of the external environment on the fracture mechanical properties. The obtained information provides a reference for further discovery of dental tissue fracture mechanical properties and serves as a guide for clinical technique and material development.

\section{CONCLUSIONS}

Studies on the mechanical properties of human teeth focus on various types of microstructural mechanical properties and factors influencing the mechanical properties. Given the complicated structure of this material, no standard measuring environment and technique exist, but the following common features have been reported:

- For enamel, the hardness and elastic modulus decrease gradually from the surface of the enamel to the DEJ, and both exhibit positive relationships with calcium content. The hardness and elastic modulus of the heads of the enamel rods are distinctly higher than those of the tail and axial cross-section. Higher hardness and elastic modulus values can be obtained in the perpendicular direction. For dentin, the variation of the hardness and elastic modulus decreases slowly toward the pulp cavity. Highly mineralized peritubular dentin has a higher Young's modulus than weakly mineralized intertubular dentin. A hydrated environment influences the mechanical behaviour of dentin.

- Nanodynamic mechanical property analysis has been applied in dentin research, and the effects of a wet environment can be clearly observed in these tests. Further research on enamel needs to be conducted.

- For enamel, crack resistance increases from outside to inside. For dentin, crack bridging, crack deflection and crack bifurcation in young hydrated dentin assist in energy dissipation and increase the 
crack growth resistance. Fatigue crack growth resistance is reduced in dry environments. Aged dentin has lower initial toughness $\left(K_{\mathrm{o}}\right)$ and stable toughness $\left(K_{\mathrm{p}}\right)$ values than young dentin. The fatigue crack growth exponent is related to the direction of the dentinal tubules.

Studies on the mechanical properties of natural teeth in complicated oral environments provide guidelines for oral clinical technique improvement (i.e., RCT technique or teeth preparation technique) and dental material development (i.e., oral restoration materials that have structure, composition and mechanical property distributions similar to those of natural teeth). Studies at the crystal level will further establish the formation mechanisms of the mechanical properties from a microscopic viewpoint and will provide a reference for the manufacture of artificial teeth using tissue engineering.

\section{ACKNOWLEDGEMENTS}

The authors acknowledge support from the National Natural Science Foundation of China (Nos. 81170996, 81070867 and 81100777) and the Sichuan Province Science and Technology Innovation Team Program (2011JTD0006).

1 He LH, Swain MV. Enamel-a "metallic-like" deformable biocomposite. J Dent 2007; 35(5): 431-437.

2 Kishen A, Ramamurty U, Asundi A. Experimental studies on the nature of property gradients in the human dentine. Biomed Mater Res 2000; 51(4): 650-659.

3 Cohen SR, Apter N, Jesse S et al. AFM investigation of mechanical properties of dentin. Isr J Chem 2008; 48(2): 65-72.

4 Habelitz S, Marshall SJ, Marshall GW Jr et al. Mechanical properties of human dental enamel on the nanometre scale. Arch Oral Biol 2001; 46(2): 173-183.

5 Kerebel B, Daculsi G, Kerebel LM. Ultrastructural studies of enamel crystallites. Dent Res 1979; 58(special issue B): 844-851.

6 Poole DF, Brooks AW. The arrangement of crystallites in enamel prisms. Arch Oral Biol 1961; 5(1): 14-26.

7 Garberoglio R, Brannstrom M. Scanning electron microscopic investigation of human dentinal tubules. Arch Oral Biol 1976; 21(6): 355-371.

8 Yu SF, Sun HC, He ZX. [Oral histopathology]. 6th ed. Beijing: People's Medical Publishing House, 2007: 70-72. Chinese.

9 Shu DL, Chen JB, Feng Y. [Engineering material mechanics]. Beijing: China Machine Press; 2006: 2-5. Chinese.

10 Chen ZQ, Zhang M, Zhang JK. [Oral materials]. 4th ed. Beijing: People's Medical Publishing House, 2008: 18-19. Chinese.

11 Loubet L, Lucas BN, Oliver WC. Some measurements of viscoelastic properties with the help of nanoindentation. NIST Spec Pub/ 1995; 896: 31-34.

12 Shu DL, Chen JB, Feng Y. [Engineering material mechanics]. Beijing: China Machine Press, 2006: 77-90. Chinese.

13 Chen ZQ, Zhang M, Zhang JK. [Oral materials]. 4th ed. Beijing: People's Medical Publishing House, 2008: 15. Chinese.

14 Shu DL, Chen JB, Feng Y. [Engineering material mechanics]. Beijing: China Machine Press, 2006: 57-63. Chinese.

15 Wang JQ. [Surface engineering manual]. Beijing: Chemical Industry Press, 1998: 856-857. Chinese.

16 Zhang TH, Yang YM. Development and application of nanohardness technique. Adv Mech 2002; 32(6): 349-364

17 Jeng YR, Lin TT, Hsu HM et al. Human enamel rod presents anisotropic nanotribological properties. Mech Behav Biomed 2011; 4(4): 515-522.

$18 \mathrm{He} \mathrm{LH}$, Yin ZH, van Vuuren LJ et al. A natural functionally graded biocomposite coating-human enamel. Acta Biomater 2013; 9(5): 6330-6337.

19 Cheng ZJ, Wang XM, Ge J et al. The mechanical anisotropy on a longitudinal section of human enamel studied by nanoindentation. J Mater Sci Mater Med 2010; 21(6): 1811-1816.

$20 \mathrm{He}$ B, Huang S, Jing J et al. Measurement of hydroxyapatite density and Knoop hardness in sound human enamel and a correlational analysis between them. Arch Oral Biol 2010; 55(2): 134-141.

21 Park S, Wang DH, Zhang D et al. Mechanical properties of human enamel as a function of age and location in the tooth. J Mater Sci Mater Med 2008; 19(6): 2317-2324.

22 He LH, Swain MV. Influence of environment on the mechanical behaviour of mature human enamel. Biomaterials 2007; 28(30): 4512-4520.

$23 \mathrm{Xu} \mathrm{HH}$, Smith DT, Jahanmir S et al. Indentation damage and mechanical properties of human enamel and dentin. J Dent Res 1998; 77(3): 472-480.

24 Meredith N, Sherriff M, Setchell DJ et al. Measurement of the microhardness and Young's modulus of human enamel and dentine using an indentation technique. Arch Oral Biol 1996; 41(6): 539-545.
25 Willems G, Celis JP, Lambrechts $P$ et al. Hardness and Young's modulus determined by nanoindentation technique of filler particles of dental restorative materials compared with human enamel. J Biomed Mater Res 1993; 27(6): 747755.

26 Zheng $\mathrm{Q}, \mathrm{Xu} \mathrm{H}$, Song $\mathrm{F}$ et al. Spatial distribution of the human enamel fracture toughness with aging. J Mech Behav Biomed Mater 2013; 26: 148-154.

$27 \mathrm{He} \mathrm{LH}$, Swain MV. Understanding the mechanical behaviour of human enamel from its structural and compositional characteristics. J Mech Behav Biomed Mater 2008; 1(1): 18-29.

28 Ang SF, Scholz T, Klocke A et al. Determination of the elastic/plastic transition of human enamel by nanoindentation. Dent Mater 2009; 25(11): 1403-1410.

29 He LH, Fujisawa N, Swain MV. Elastic modulus and stress-strain response of human enamel by nano-indentation. Biomaterials 2006; 27(24): 4388-4398.

30 Cuy JL MA, Livi KJ et al. Nanoindentation mapping of the mechanical properties of human molar tooth enamel. Arch Oral Biol 2002; 47(4): 281-291.

31 Roy S, Basu B. Mechanical and tribological characterization of human tooth. Mater Charact 2008; 59(6): 747-756.

32 Park S, Wang DH, Zhang $\mathrm{D}$ et al. Mechanical properties of human enamel as a function of age and location in the tooth. J Mater Sci Mater Med 2007; 19(6): 2317-2324.

33 Featherstone JD, ten Cate JM, Shariati M et al. Comparison of artificial caries-like lesions by quantitative microradiography and microhardness profiles. Caries Res 1983; 17(5): 385-391.

34 Kodaka T, Debari K, Yamada M et al. Correlation between microhardness and mineral content in sound human enamel. Caries Res 1992; 26(2): 139-141.

35 Buchalla W, Imfeld T, Attin T et al. Relationship between nanohardness and mineral content of artificial carious enamel lesions. Caries Res 2008; 42(3): 157-163.

$36 \mathrm{He}$ B, Huang SB, Jing JJ et al. Measurement of hydroxyapatite density and Knoop hardness in sound human enamel and a correlational analysis between them. Arch Oral Biol 2010; 55(2): 134-141.

37 Gutiérrez-Salazar M, Reyes-Gasga J. Microhardness and chemical composition of human tooth. Mater Res 2003; 6(3): 367-373.

38 Braly A, Darnell LA, Mann AB et al. The effect of prism orientation on the indentation testing of human molar enamel. Arch Oral Biol 2007; 52(9): 856-860.

39 Mahoney E, Holt A, Swain M et al. The hardness and modulus of elasticity of primary molar teeth: an ultra-micro-indentation study. J Dent 2000; 28(8): 589-594.

40 Fong $\mathrm{H}$, White $\mathrm{SN}$, Paine $\mathrm{ML}$ et al. Enamel structure properties controlled by engineered proteins in transgenic mice. J Bone Miner Res 2003; 18(11): 2052-2059.

$41 \mathrm{Xie} \mathrm{ZH}$, Mahoney EK, Kilpatrick NM et al. On the structure-property relationship of sound and hypomineralized enamel. Acta Biomater 2007; 3(6): 865-872.

42 Malek S, Darendeliler MA, Swain MV. Physical properties of root cementum: Part I. A new method for 3-dimensional evaluation. Am J Orthod Dentofacial Orthop 2001; 120(2): 198-208.

43 Malek S, Darendeliler MA, Rex T et al. Physical properties of root cementum: part 2. Effect of different storage methods. Am J Orthod Dentofacial Orthop 2003; 124(5): 561-570.

44 Angker L, Swain MV, Kilpatrick N. Characterising the micro-mechanical behaviour of the carious dentine of primary teeth using nano-indentation. J Biomech 2005; 38(7): 1535-1542.

45 He LH, Swain MV. Nanoindentation derived stress-strain properties of dental materials. Dent Mater 2007; 23(7): 814-821.

46 Ryou H, Romberg E, Pashley DH et al. Nanoscopic dynamic mechanical properties of intertubular and peritubular dentin. J Mech Behav Biomed Mater 2012; 7: 3-6.

47 Ho SP, Pavla S, Grayson WM et al. Structure, chemical composition and mechanical properties of coronal cementum in human deciduous molars. Dent Mater 2009, 25(10): 1195-1204.

48 Sunita PH, Yu B, Yun WB et al. Structure, chemical composition and mechanical properties of human and rat cementum and its interface with root dentin. Acta Biomater 2009; 5(2): 707-718.

49 Ryou H, Niu LN, Dai L et al. Effect of biomimetic remineralization on the dynamic nanomechanical properties of dentin hybrid layers. J Dent Res 2011; 90(9): 1122-1128.

50 Park S, Quinn JB, Romberg E, et al. On the brittleness of enamel and selected dental materials. Dent Mater 2008; 24(11): 1477-1485.

51 Pupo YM, Michél MD, Gomes OM et al. Effect of the regional variability of dentinal substrate and modes of application of adhesive systems on the mechanical properties of the adhesive layer. J Conserv Dent 2012; 15(2): 132-136.

52 Karlinsey RL, Mackey AC, Walker TJ et al. In vitro remineralization of human and bovine white-spot enamel lesions by NaF dentifrices: a pilot study. J Dent Oral Hyg 2011; 3(2): 22-29.

53 Ivancik J, Majd H, Bajaj D, et al. Contributions of aging to the fatigue crack growth resistance of human dentin. Acta Biomater 2012; 8(7): 2737-2746.

54 Nazari A, Bajaj D, Zhang D et al. Aging and the reduction in fracture toughness of human dentin. J Mech Behav Biomed Mater 2009; 2(5): 550-559.

55 Zhang D, Mao S, Lu C et al. Dehydration and the dynamic dimensional changes within dentin and enamel. Dent Mater 2009; 25(7): 937-945.

56 Bajaj D, Sundaram N, Nazari A et al. Age, dehydration and fatigue crack growth in dentin. Biomaterials 2006; 27(11): 2507-2517.

57 Wang RZ, Weiner S. Strain-structure relations in human teeth using Moiré fringes. J Biomech 1997; 31(2): 135-141.

58 Ziskind D, Hasday M, Cohen SR et al. Young's modulus of peritubular and intertubular human dentin by nano-indentation tests. J Struct Biol 2011; 174(1): 23-30.

59 Angker L, Nijhof C, Swain MV et al. Correlating the mechanical properties to the mineral content of carious dentine-a comparative study using an ultra-micro 
indentation system (UMIS) and SEM-BSE signals. Arch Oral Biol2004; 49(5): 369 378.

60 Kinney JH, Nalla RK, Pople JA et al. Age-related transparent root dentin: mineral concentration, crystallite size, and mechanical properties. Biomaterials 2005 26(16): 3363-3376.

61 Guidoni G, Denkmayr T, Schöberl T et al. Nanoindentation in teeth: influence of experimental conditions on local mechanical properties. Philos Mag 2006; 86(33/ 34/35): 5705-5714.

62 Kinney JH, Gladden J, Marshall GW et al. Resonant ultrasound spectroscopy measurements of the elastic constants of human dentin. J Biomech 2004; 37(4): 437-441.

63 Bertassoni LE, Swain MV. Influence of hydration on nanoindentation induced energy expenditure of dentin. J Biomech 2012; 45(9): 1679-1683.

64 Balooch G, Marshall GW, Marshall SJ et al. Evaluation of a new modulus mapping technique to investigate microstructural features of human teeth. J Biomech 2004; 37(8): 1223-1232.

65 Koester KJ, Ager JW 3rd, Ritchie RO. The effect of aging on crack-growth resistance and toughening mechanisms in human dentin. Biomaterials 2008; 29(10): 1318-1328.

66 Arola DD, Reprogel RK. Tubule orientation and the fatigue strength of human dentin. Biomaterials 2006; 27(9): 2131-2140.

67 Juliana I, Arola DD. The importance of microstructural variations on the fracture toughness of human dentin. Biomaterials 2013; 34(4): 864-874.

68 Toparli M, Aksoy T. Fracture toughness determination of composite resin and dentin/ composite resin adhesive interfaces by laboratory testing and finite element models. Dent Mater 1998; 14(4): 287-293.

69 Zhang D, Nazari A, Soappman M et al. Methods for examining the fatigue and fracture behavior of hard tissues. Exp Mech 2007; 47(3): 325-336.

70 Kruzic JJ, Nalla RK, Kinney JH et al. Mechanistic aspects of in vitro fatigue-crack growth in dentin. Biomaterials 2005; 26(10): 1195-1204.

71 Kruzic JJ, Ritchie RO. Fatigue of mineralized tissues: cortical bone and dentin. J Mech Behav Biomed 2008; 1(1): 3-17.

72 Bajaj D, Nazari A, Eidelman $\mathrm{N}$ et al. A comparison of fatigue crack growth in human enamel and hydroxyapatite. Biomaterails 2008; 29(36): 4847-4854.
73 Yan J, Taskonak B, Mecholsky JJ Jr. Fractography and fracture toughness of human dentin. J Mech Behav Biomed 2009; 2(5): 478-484.

74 Padmanabhan SK, Balakrishnan A, Chu MC et al. Micro-indentation fracture behavior of human enamel. Dent Mater 2010; 26(1): 100-104.

75 Yan J, Baskonak T, Platt JA et al. Evaluation of fracture toughness of human dentin using elastic-plastic fracture mechanics. J Biomech 2008; 41(6): 1253-1259.

76 Kruzic JJ, Nalla RK, Kinney JH et al. Crack blunting, crack bridging and resistancecurve fracture mechanics in dentin: effect of hydration. Biomaterials 2003; 24(28): 5209-5221.

77 Chai H, Lee JJ, Lawn BR. Fracture of tooth enamel from incipient microstructural defects. J Mech Behav Biomed 2010; 3(1): 116-120.

78 Bajaj D, Arola DD. On the R-curve behavior of human tooth enamel. Biomaterials 2009; 30(23/24): 4037-4046.

79 Bajaj D, Arola D. Role of prism decussation on fatigue crack growth and fracture of human enamel. Acta Biomater 2009; 5(8): 3045-3056.

80 Nalla RK, Kinney JH, Ritchie RO. Effect of orientation on the in vitro fracture toughness of dentin: the role of toughening mechanisms. Biomaterials 2003; 24(22): 3955-3968.

81 Wang RZ. Anisotropic fracture in bovine root and coronal dentin. Dent Mater 2005; 21(5): 429-436.

82 Arola D, Reid J, Cox ME et al. Transition behavior in fatigue of human dentin: structure and anisotropy. Biomaterials 2007; 28(26): 3867-3875.

(c) (i) $€$ This work is licensed under a Creative Commons Attribution-

cc) $(1)$ BY NC ND NonCommercial-NoDerivs 3.0 Unported License. The images or other third party material in this article are included in the article's Creative Commons license, unless indicated otherwise in the credit line; if the material is not included under the Creative Commons license, users will need to obtain permission from the license holder to reproduce the material. To view a copy of this license, visit http://creativecommons.org/licenses/ by-nc-nd/3.0/ 